\title{
The young consumer perception toward clean label: halal clean food
}

\author{
Nesrine KHAZAMI \\ Szent István University, 2100 Gödöllő, Páter K. u. 1.; E-mail: nessrinekhazami@gmail.com
}

Keywords: Clean Food, Consumer, Halal, Label, Perception.

\section{Introduction}

Most of industrialized countries became afflicted about food insecurity with the key contribution of agrifood industrialization (lusk, 2016; Menses, Cannon, \& Flores, 2014). Consumers are becoming more concerned with food quality and health issues and start searching for some clues that facilitate and ease their searching and evaluation process. So that, marketers start to target those customer segments by positioning their products as halal food or clean label food to be considered as a trust attribute for their products, and consumers would depend on its brand credibility. However, number of trends have emerged in conjunction with the halal food and clean label movement as opportunities for food makers to connect and resonate with their target audience (Shelke \& Kim, 2018). So, in this study we will try to find the possibility of considering halal food as a clean label food and targeting other segment rather than Muslims with this straddle positioning strategy.

\section{Materials and methods}

According to previous studies Halal logo did play a role in the Muslim and non- Muslim consumer's purchase decision (Shaari \& Nur Shahira, 2009; Golnaz, Zainulabidin, Mad Nasir, \& Eddie Chiew, 2010). Consumers had no means or time to check or obtain the necessary information on the products to satisfy their principles when making a purchase. Thus, the Halal logo is the label they can rely on in determining the Halal status of a product (Zakaria, 2008). Alternatively, the Muslim consumers generally check and identified from which country a food product is originated before purchasing them (Ahmad, 2008). In this paper, we will follow a desk research methodology that depends on previous studies and literatures that covered the topics of halal food and the application of clean label concept in food industries and try to determine consumer behavior toward those two concepts.

\section{Results and discussion}

In the past few decades the halal food trade mark grows enormously and starts to appear in almost all over the world. Halal products are targeting Muslims consumers who want to consume products that compatible with their religious beliefs. Halal food principles are all about consuming clean food that don't harm consumers by any way, and it covers booth of food ingredients and production process. Another labeling strategy that used by food marketers nowadays is clean label. Clean label positioning depends on consumer perception for their needs to consume healthy foods that's free from harmful artificial ingredients which require food producers to be selective in choosing their products ingredients and production process. And since both of halal food and clean label concepts sharing the principles of being healthy and unharmful, we aimed in this study to identify the relationship between halal food and clean label by reviewing the previous literature that covered the two concept and examine the role of halal clean food for the new young 
Muslim and non- Muslim consumer and then investigate the role of halal clean food for the marketers as a branding element to attract new Muslim and non- Muslim markets and Suggest a positioning strategy for marketers of halal food to target non-Muslims segment by using the clean label concept.

\section{Conclusions}

According to our review for previous literature, and after reviewing the different definitions for clean label and halal food and since food is a vital component for livelihood. We can conclude that Halal rules are not only concerned only with safety, hygiene, and wholesomeness of the foods, but also provide an excellent platform for healthy eating standards. Also, Halal food industry needs innovation, progression and expansion. This research is of boundless position for the food manufacturers, distributors, suppliers and marketers in Muslim and non- Muslim market. This study is an initial point for the marketers to promote and create awareness among the consumers and to understand the need of halal clean food logo to improve the brand trustiness because many halal food products available in market have halal logo, but it has lack credibility. And her we suggest halal food marketers to use a positioning strategy that could targeting non-Muslim segment by introducing their product as a Halal clean label product.

\section{References}

Ahmad, A. (2008): Marketing of halal meat in the United Kingdom. British Food Journal, 110(7), 655-670. https://doi.org/10.1108/00070700810887149

Golnaz, R., Zainulabidin, M., Mad Nasir, S., \& Eddie Chiew, F. (2010): Non- Muslim perception awareness of halal principle and related food products in Malaysia . International Food Research Journal, 17, 667- 674.

Lusk, J. L. (2016): unnaturally delicious: how since and techonology are serving up super foods to serve the world. New York: St.Martins Press.

Menses, Y., Cannon, K. J., \& Flores, R. A. (2014): keys to understanding and addressing consumer perceptions and concerns about processed foods. Cereal Foods World, 59(3), 141-146. https://doi.org/10.1094/cfw-593-0141

Shaari, J., \& Nur Shahira, M. (2009): Dimension of Halal Purchase Intention: A Preliminary Study. Australia: Paper Presented At The Eleventh International Business Research Conference.

Shelke, K., \& Kim, J. (2018, January): keep it clean: „Clean label” has become the brass ring for food manufacturers. Prepared Foods, 187(1), pp. 58-72.

Zakaria, Z. (2008): Tapping into the world halal market: some discussions on Malaysian laws and standards. Shariah Journal, 16, 603-616. 